\title{
Evaluation of Linter Cellulose as an Alternative Raw Material for Tissue Paper Production
}

\section{Procjena linter celuloze kao alternativne sirovine za proizvodnju upijajućeg papira}

\author{
Original scientific paper • Izvorni znanstveni rad \\ Received - prispjelo: 28. 11. 2016. \\ Accepted - prihvaćeno: 1. 12. 2017. \\ UDK: $630 * 813.13 ; 630 * 861.0$ \\ doi:10.5552/drind.2017.1647
}

\begin{abstract}
The study was carried out to evaluate Linter Cellulose $(L C)$ as an alternative raw material for tissue paper production. Since LC is generally dark brown in color, it must be bleached before being used in tissue paper production. Bleaching process was applied to LC after impurities and oils were removed. LC was bleached in 9 different conditions with sodium hypochlorite ( $\mathrm{NaClO}$ ). The optical and physical properties of LC were measured in accordance with relevance standards in order to determine optimum bleaching condition. The best results in the optical properties were obtained by bleaching with $12 \% \mathrm{NaClO}$. The whiteness, brightness, and yellowness values were found as 67.54, 64.39, and 6.20, respectively. The physical properties of bleached LC were not suitable for tissue paper production. For this reason, LC and wood fibers (WF) were mixed at certain rates to produce tissue paper. The physical and optical properties of the paper obtained from the mixtures were analyzed to determine the optimum mixing ratio. The results showed that $40 \%$ LC and $60 \%$ WF mixtures can be used in tissue paper products. The important physical properties for tissue paper were Water Retention Value(WRV) and Water Absorption Time (WAT) and these values were found as $293.6 \mathrm{~g} \cdot \mathrm{m}^{-2}$ and $1.67 \mathrm{~s}$. WRV and WAT of LC were found to be better than those of WF (267 $\mathrm{g} \cdot \mathrm{m}^{-2}$ and $\left.2.62 \mathrm{~s}\right)$. As a result, when considering the shortage of pulp and paper raw material, the use of LC in tissue paper production would contribute significantly to procuring the raw material and providing economic production.
\end{abstract}

Keywords: Linter cellulose, bleaching, sodium hypochlorite, tissue paper.

SAŽETAK • Istraživanje je provedeno radi procjene linter celuloze (LC) kao alternativne sirovine za proizvodnju upijajućeg papira. Budući da je LC tamnosmeđe boje, prije uporabe za proizvodnju upijajućeg papira potrebno ga je izbijeliti. Procesi izbjeljivanja LC-a primijenjeni su nakon uklanjanja nečistoća i ulja. LC je izbijeljen natrijevim hipokloridom (NaClO) pri devet različitih uvjeta. Izmjerena su optička i fizikalna svojstva LC-a u skladu s odgovarajućim standardima kako bi se odredili optimalni uvjeti izbjeljivanja. Najbolji rezultati optičkih svojstava dobiveni su izbjeljivanjem 12-postotnim NaClO. Vrijednost bjeline iznosila je 67,54\%, sjajnosti 64,39 \% i žutila 6,20 \%. Fizikalna svojstva izbijeljenog LC-a nisu prikladna za proizvodnju upijajućeg papira. Stoga je LC pomiješan s drvnim vlakancima (WF) u određenom omjeru kako bi se dobila sirovina prikladna za proizvodnju upijajućeg papira. Fizikalna i optička svojstva papira proizvedenoga od pripremljene smjese analizirana su radi određivanja optimalnog omjera miješanja LC-a i WF-a. Rezultati su pokazali da je smjesa od $40 \%$ LC-a i $60 \%$

\footnotetext{
${ }^{1}$ Authors are professor and assistants at Department of Forest Industry Engineering, Faculty of Forestry, Kahramanmaras Sutcu Imam University, Kahramanmaras, Turkey.

${ }^{1}$ Autori su profesor i asistenti Odsjeka za industrijsku preradu drva, Šumarski fakultet, Sveučilište Kahramanmaras Sutcu Imam, Kahramanmaras, Turska.
} 
WF-a može upotrebljavati za izradu proizvoda od upijajućeg papira. Važna fizikalna svojstva upijajućeg papira jesu sposobnost zadržavanja vode (WRV) i vrijeme upijanja vode (WAT). Za proizvedeni upijajući papir izmjerena je vrijednost WRV-a od 293,6 $\mathrm{g} \cdot \mathrm{m}^{-2}$ i WAT-a od 1,67 s. Utvrđeno je da su vrijednosti WRV-a i WAT-a za LC bolje nego vrijednosti za WF (267 $\mathrm{g} \cdot \mathrm{m}^{-2}$ i 2,62 s). Kada se uzme u obzir nedostatak sirovine za proizvodnju celuloze $i$ papira, može se reći da bi upotreba LC-a za proizvodnju upijajućeg papira mogla znatno pridonijeti lakšoj nabavi sirovina i ekonomičnosti proizvodnje.

\section{Ključne riječi: linter celuloza, izbjeljivanje, natrijev hipoklorit, upijajući papir}

\section{INTRODUCTION}

\section{UVOD}

Cellulose, the raw material of the paper, is obtained from wood and non-wood plants. Due to the use of wood raw materials in different industries (particleboard, plywood, furniture etc.), it has become an expensive raw material. In addition to this, since the process of obtaining wood takes a very long period of time, cellulose production from annual plants has become more attractive (Erdem, 2010). Cotton, one of these annual plants, is primarily grown as textile raw material. Linter is obtained as a by-product from the cotton seed. When compared with wood, cellulose can be more easily obtained from linter. Besides, it is also easier to bleach linter than wood pulps.

The decrease in the availability of raw materials for pulp and paper production has led papermakers to search for new raw material resources. Several studies have been carried out to discover these resources (Chandra, 1998; Tutus and Cicekler, 2016; Comlekcioglu et al., 2016). As an alternative to wood-based raw materials, linter cellulose is an important raw material resource for pulp and paper production. Linter is an important byproduct of the textile industry. Cotton linter is the short fiber that cannot be used in the textile process. In order to be used in oil production, cotton seed must be separated from its seed by special cutting methods. After special cutting methods, first and second cut linters are obtained from separated fibers. Cellulose content, color, fiber dimension, and contaminants are important to determine the quality of linter cellulose (LC). Linter has an excess of $80 \%$ of holocellulose, and more than $75 \%$ of it is alpha-cellulose (Dogmaz, 1994; Sczostak, 2009; Morais et al., 2013). LC was first applied in regenerated cellulose production. Also, LC is used in the production of cellulose esters such as nitro cellulose and cellulose acetate (Ward et al., 1965).

The type raw material is one of the most important factors affecting paper quality. Chemical components and fiber properties of wood differ from species to species. For this reason, the characteristics of the pulps produced in certain pulping conditions depend on the wood species (Perez and Funchon, 2003; Shackford, 2003). Softwood pulps are used to produce stronger paper. These pulps are often used as reinforcing pulp in paper production. On the other hand, hardwood pulps are preferred for producing smooth and high-quality writing paper (Chauhan et al., 2011; Gulsoy and Tufek, 2013).

Bleaching is a chemical process applied to enhance the brightness of cellulosic materials. It is possible to increase the service and usage area of the paper with the bleaching process (Reeve, 1996). The main purpose of the bleaching process is to modify and/or remove the lignin and lignin degradation products, extractive substances, metal ions, non-cellulosic carbohydrate components and any coloring materials in the paper poultry by using appropriate chemical substances and systems (Singh, 1978). Sodium hypochlorite $(\mathrm{NaClO})$ is stable above $\mathrm{pH} 10$ (Cardamone and Marmer, 1995). It is a very cheap oxidizer, with higher redox potential than hydrogen peroxide, and bleaches rapidly at room temperature (Karmakar, 1999; Ibrahim et al., 2010).

Tissue paper is produced by a paper machine that has a single large steam heated drying cylinder (yankee dryer) fitted with a hot air hood. The raw material is paper pulp. The Yankee cylinder is sprayed with adhesives to make the paper stick. Creping is done by the Yankee's doctor blade that is scraping the dry paper off the cylinder surface. The crinkle (crêping) is controlled by the strength of the adhesive, geometry of the doctor blade, speed difference between the Yankee and final section of the paper machine and paper pulp characteristics (Paulapuro, 2000).

Generally, LC has been burned for energy production in the world. However, there is little to no information on the application of this resource for tissue paper production. The objective of this study was to evaluate LC for tissue paper production in the mixture with wood fibers.

\section{MATERIALS AND METHODS 2. MATERIJALI I METODE}

\subsection{Materials}

2.1. Materijali

This study was performed at the Kahramanmaras Sutcu Imam University Faculty of Forestry, Pulp, and Paper Production Laboratory. LC was taken from Pakmil Oil and Cotton Industry Enterprises Inc., in Adana-Turkey and its fiber length and viscosity values are $2.95-3.00 \mathrm{~mm}$ and $1300-1350 \mathrm{cp}$, respectively. The bleached wood pulps, containing $70 \%$ of short fibers (hardwood) and $30 \%$ of long fibers (softwood), were supplied from Kombassan Paper Mill. Chemicals were supplied by Merck (Darmstadt, Germany). Raw material was prepared and physical and optical properties of tissue paper were determined according to the relevant standard methods.

\subsection{Preparation of LC pulps}

2.2. Priprema LC pulpe

Firstly, LCs was cleaned from rough and non-fibrous contamination. Then, it was kept into cold water 
(24 h) and hot water (4 h) in order to remove impurities and oils. Alkali extraction removed a large part of the hemicellulose from linter fibers and decreased the content of the charged groups (Lund et al., 2012). Before bleaching of linter cellulose, alkali extraction was applied at three different rates $8 \%, 10 \%$, and $12 \%$. After alkali extraction, LC was beaten in a hollander beater to $40 \pm 5$ 'SR freeness, according to TAPPI standard T200 sp-96. All LC pulps were screened on a $0.15 \mathrm{~mm}$ slotted screen to remove non-fibrous matters. Test papers were produced from these LC pulps in order to determine optimum alkali extraction condition. According to the results, $10 \%$ alkali extraction gave the best result in terms of the yield and optical properties. These pulps were subjected to $\mathrm{NaClO}$ bleaching processes.

\subsection{Bleaching of LC pulps}

2.3. Izbjeljivanje LC pulpe

LC pulps were bleached with $\mathrm{NaClO}$ in 9 different conditions given in Table 1 . Time and temperature were kept constant, while $\mathrm{NaClO}$ rate and consistency were changed during bleaching processes.

After preparing the bleaching liquors given in Table 1 , the pulps were placed in polyethylene bags. Then, the mixtures were put in a water bath, where the temperature was controlled by a thermostat. Fig. 1 presents the stages of the bleaching process. At the end of bleaching, the pulps were pressed up to 20-25 \% dryness. The values of whiteness, brightness, and yellowness of the pulps were measured by a color-measuring instrument Datacolor Elrepho in accordance with applicable standards.

After bleaching, the LC pulps were taken out from the water bath and washed with hot and cold water until chemicals were completely removed from the pulp.
Table $1 \mathrm{NaClO}$ bleaching conditions of Linter Cellulose Tablica 1. Uvjeti izbjeljivanja linter celuloze uz pomoć $\mathrm{NaClO}$

\begin{tabular}{|c|c|c|c|c|}
\hline $\begin{array}{c}\text { Bleaching } \\
\text { Number } \\
\text { Redni broj } \\
\text { izbjeljivanja }\end{array}$ & $\begin{array}{c}\text { NaClO } \\
\text { Charge } \\
\text { Udjel } \\
\text { NaClO } \\
\%\end{array}$ & $\begin{array}{c}\text { Consist- } \\
\text { ency } \\
\text { Konzist- } \\
\text { encija } \\
\%\end{array}$ & $\begin{array}{c}\text { Tempera- } \\
\text { ture } \\
\text { Tempera- } \\
\text { tura } \\
{ }^{\circ} \mathrm{C}\end{array}$ & $\begin{array}{c}\text { Time } \\
\text { Vri- } \\
\text { jeme } \\
\text { min }\end{array}$ \\
\hline 1 & 8 & 8 & 60 & 60 \\
\hline 2 & 8 & 12 & 60 & 60 \\
\hline 3 & 8 & 16 & 60 & 60 \\
\hline 1 & 12 & 8 & 60 & 60 \\
\hline 2 & 12 & 12 & 60 & 60 \\
\hline 3 & 12 & 16 & 60 & 60 \\
\hline 1 & 16 & 8 & 60 & 60 \\
\hline 2 & 16 & 12 & 60 & 60 \\
\hline 3 & 16 & 16 & 60 & 60 \\
\hline
\end{tabular}

\subsection{Tissue paper production with bleached linter} cellulose and wood fiber

2.4. Proizvodnja upijajućeg papira od izbijeljene linter celuloze i drvnih vlakanaca

Test papers were produced from bleached LC and the optical properties of these papers were analyzed. Bleached LC pulps with $12 \% \mathrm{NaClO}$ at $8 \%$ consistency gave the best results in the optical properties among 9 different bleaching levels. The physical properties of bleached LC were not suitable for tissue paper production. For this reason, LC and wood fibers (WF) were mixed at certain rates to produce tissue paper given in Table 2. As shown in the table, tissue paper was made using 11 different mixture rates. Ten handsheets per tested sequence, with the grammage of $30 \pm 5$ $\left(\mathrm{g} \cdot \mathrm{m}^{-2}\right)$, were prepared using a British Sheet Former according to TAPPI T 205 sp-02.
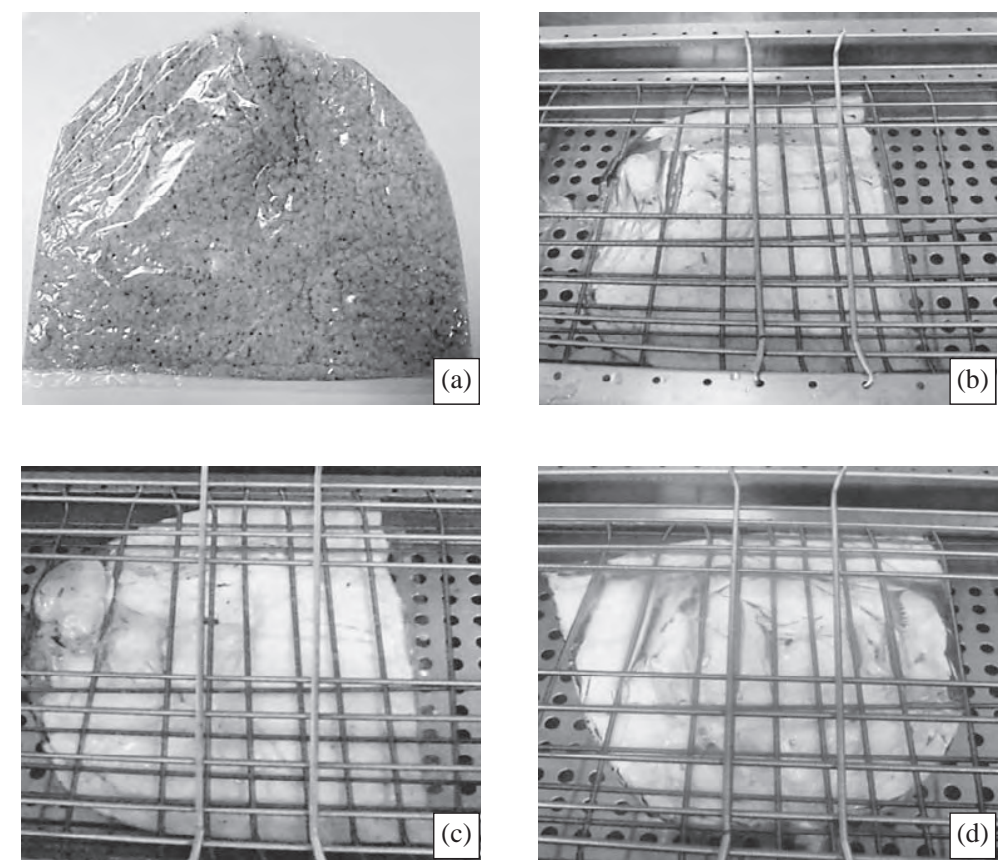

Figure 1 Bleaching stages: before (a), after 15 min (b), after 30 min (c), after 60 min (d)

Slika 1. Prikaz faza izbjeljivanja: a) prije izbjeljivanja, b) 15 minuta nakon izbjeljivanja, c) 30 minuta nakon izbjeljivanja, d) 60 minuta nakon izbjeljivanja 
Tutuş, Özdemir, Çiçekler: Evaluation of Linter Cellulose as an Alternative Raw Material... ...

Table 2 Mixing rates of LC and wood fiber

Tablica 2. Omjeri miješanja linter celuloze i drvnih vlakanaca

\begin{tabular}{|c|c|c|}
\hline Mixture No / Broj smjese & $\begin{array}{c}\text { Linter cellulose / Linter celuloza } \\
\%\end{array}$ & $\begin{array}{c}\text { Wood fiber / Drvna vlakanca } \\
\%\end{array}$ \\
\hline 1 & 0 & 100 \\
\hline 2 & 10 & 90 \\
\hline 3 & 20 & 80 \\
\hline 4 & 30 & 70 \\
\hline 5 & 40 & 60 \\
\hline 6 & 50 & 50 \\
\hline 7 & 60 & 40 \\
\hline 8 & 70 & 30 \\
\hline 9 & 80 & 20 \\
\hline 10 & 90 & 10 \\
\hline 11 & 100 & 0 \\
\hline
\end{tabular}

Table 3 Tests applied on tissue paper and applicable standards

Tablica 3. Provedeno ispitivanje upijajućeg papira i primijenjeni standardi

\begin{tabular}{|c|c|c|c|}
\hline $\begin{array}{l}\text { Physical and optical properties } \\
\text { Fizikalna i optička svojstva }\end{array}$ & $\begin{array}{l}\text { Napkin } \\
\text { Ubrus }\end{array}$ & $\begin{array}{c}\text { Paper towel } \\
\text { Papirnati ručnik }\end{array}$ & $\begin{array}{c}\text { Toilet paper } \\
\text { Toaletni papir }\end{array}$ \\
\hline Grammages / gramaža, g.m-2 & ISO 12625 & ISO 12625 & ISO 12625 \\
\hline Moisture content / sadržaj vode, \% & ISO 12625 & ISO 12625 & ISO 12625 \\
\hline Whiteness / bjelina (ISO) & ISO 11476 & ISO 11476 & ISO 11476 \\
\hline Brightness / sjajnost (ISO) & ISO 2470 & ISO 2470 & ISO 2470 \\
\hline Yellowness / žutilo (ISO) & ISO 5631 & ISO 5631 & ISO 5631 \\
\hline Thickness / debljina, $\mu \mathrm{m}$ & ISO 12625 & ISO 12625 & ISO 12625 \\
\hline Bulkiness / obujmnost, $\mathrm{cm}^{-3} \cdot \mathrm{g}$ & ISO 287 & ISO 2470 & ISO 12625 \\
\hline Density / gustoća, $\mathrm{g} \cdot \mathrm{cm}^{-3}$ & ISO 287 & ISO 2470 & ISO 12625 \\
\hline Breaking length / duljina lomljenja, m & ISO 1924/2 & ISO 1924/2 & ISO 12625 \\
\hline Water absorption time / vrijeme upijanja vode, $\mathrm{s}$ & ISO 12625 & ISO 12625 & ISO 12625 \\
\hline Water retention value / vrijednost zadržavanja vode, $\mathrm{g} \cdot \mathrm{m}^{-2}$ & ISO 12625 & ISO 12625 & ISO 12625 \\
\hline
\end{tabular}

Wood fibers used in this study consist of hardwood (70 \%) and softwood (30 \%) fibers. They were also beaten in a Hollander beater to $40 \pm 5^{\circ} \mathrm{SR}$ before being mixed with bleached LC pulps.

\subsection{Determining physical and optical properties of tissue paper \\ 2.5. Određivanje fizikalnih i optičkih svojstava} upijajućeg papira

The test papers were conditioned at $23 \pm 1{ }^{\circ} \mathrm{C}$ and $65 \%$ relative humidity in the conditioning room in accordance with TAPPI T 402 om-88 standard. Then, they were prepared for physical and optical tests. Tests were performed according to the standards given in Table 3.

Regression analysis was performed to determine the effect of LC on physical and optical test results of the paper obtained from WF and LC mixtures, and $R^{2}$ values were calculated and plotted in the figures bellow.

\section{RESULTS AND DISCUSSION}

3. REZULTATI I RASPRAVA

The optical properties and yields of LC pulps subjected to alkali extraction are presented in Table 4.

According to Table 4, as the alkali charge increased, the optical properties of the LC pulps increased at first, then decreased. Alkali extraction re-
Table 4 Optical properties and yields of LC pulps after alkali extraction

Tablica 4. Optička svojstva i prinos pulpe LC-a nakon ekstrakcije lužinom

\begin{tabular}{|l|c|c|c|}
\hline NaOH charge / Udjel $\mathrm{NaOH}, \%$ & $8 \%$ & $10 \%$ & $12 \%$ \\
\hline Whiteness / Bjelina (ISO) & 37.09 & 41.10 & 40.22 \\
\hline Brightness / Sjajnost (ISO) & 29.63 & 33.66 & 33.37 \\
\hline Yellowness / Žutilo (ISO) & 29.25 & 25.85 & 27.35 \\
\hline Yield / Prinos, \% & 93.81 & 89.99 & 88.62 \\
\hline
\end{tabular}

moves a large amount of hemicellulose and causes the yield loss. For this reason, the yields decreased with increasing lkali charge. As $10 \% \mathrm{NaOH}$ charge resulted in the best optical properties, these pulps were subjected to $\mathrm{NaClO}$ bleaching process.

Bleached LC handsheets, with the grammage of $70 \pm 5\left(\mathrm{~g} \mathrm{~m}^{-2}\right)$, were prepared to determine optical properties in order to better understand the bleaching efficiency. The yields and optical properties of LC pulps bleached with $\mathrm{NaClO}$ are given in Table 5.

As can be seen in Table 5, the best optical properties were obtained from LC pulps bleached with $12 \%$ $\mathrm{NaClO}$. In the same table, pulps bleached at $8 \%$ consistency resulted in the best optical properties. According to these results, pulps bleached with $12 \% \mathrm{NaClO}$ at $8 \%$ consistency were used for tissue paper produc- 
... Tutuş, Özdemir, Çiçekler: Evaluation of Linter Cellulose as an Alternative Raw Material...

Table 5 Optical properties and yields of LC pulps bleached with $\mathrm{NaClO}$

Tablica 5. Optička svojstva i prinos pulpe LC-a izbijeljene uz pomoć NaClO

\begin{tabular}{|c|c|c|c|c|c|c|c|c|c|}
\hline $\begin{array}{l}\text { NaClO Charge } \\
\text { Udjel } \mathrm{NaClO}, \%\end{array}$ & \multicolumn{3}{|c|}{$8 \%$} & \multicolumn{3}{|c|}{$12 \%$} & \multicolumn{3}{|c|}{$16 \%$} \\
\hline \multirow{2}{*}{$\begin{array}{l}\text { Pulp properties } \\
\text { Svojstva pulpe }\end{array}$} & \multicolumn{3}{|c|}{$\begin{array}{c}\text { Consistency, \% } \\
\text { Konzistentnost, \% }\end{array}$} & \multicolumn{3}{|c|}{$\begin{array}{c}\text { Consistency, \% } \\
\text { Konzistentnost, \% }\end{array}$} & \multicolumn{3}{|c|}{$\begin{array}{c}\text { Consistency, \% } \\
\text { Konzistentnost, \% } \\
\end{array}$} \\
\hline & $8 \%$ & $12 \%$ & $16 \%$ & $8 \%$ & $12 \%$ & $16 \%$ & $8 \%$ & $12 \%$ & $16 \%$ \\
\hline $\mathrm{pH}$ & 10.4 & 10.2 & 10.1 & 10.5 & 10.3 & 10.2 & 10.6 & 10.8 & 11.0 \\
\hline Viscosity / viskoznost, $\mathrm{cm}^{2} \cdot \mathrm{gr}^{-1}$ & 1013 & 1086 & 1105 & 983 & 997 & 1001 & 956 & 977 & 981 \\
\hline Fiber length / duljina vlakanaca, mm & 2.60 & 2.63 & 2.66 & 2.48 & 2.48 & 2.50 & 2.32 & 2.33 & 2.40 \\
\hline Whiteness / bjelina (ISO) & 76.87 & 75.91 & 76.88 & 76.57 & 76.25 & 76.26 & 75.97 & 73.06 & 73.13 \\
\hline Brightness / sjajnost (ISO) & 71.38 & 70.67 & 71.47 & 73.47 & 72.34 & 72.22 & 72.23 & 68.87 & 68.78 \\
\hline Yellowness / žutilo (ISO) & 9.34 & 9.02 & 9.20 & 5.54 & 6.64 & 6.92 & 6.34 & 7.40 & 7.79 \\
\hline Yield / prinos, \% & 85.40 & 91.60 & 88.75 & 85.80 & 82.80 & 83.64 & 81.96 & 79.96 & 82.88 \\
\hline
\end{tabular}

Table 6 Optical properties of tissue paper obtained with mixed pulps

Tablica 6. Optička svojstva upijajućeg papira proizvedenoga od različitih smjesa pulpe

\begin{tabular}{|l|c|c|c|}
\hline $\begin{array}{l}\text { Mixture rates, \% } \\
\text { Omjer smjese, \% }\end{array}$ & $\begin{array}{c}\text { Whiteness } \\
\text { (ISO) } \\
\text { Bjelina } \\
\text { (ISO) }\end{array}$ & $\begin{array}{c}\text { Brightness } \\
\text { (ISO) } \\
\text { Sjajnost } \\
\text { (ISO) }\end{array}$ & $\begin{array}{c}\text { Yellow- } \\
\text { ness (ISO) } \\
\text { Žutilo } \\
\text { (ISO) }\end{array}$ \\
\hline 100 WF & 70.99 & 69.07 & 3.60 \\
\hline 90 WF+10 LC & 70.21 & 68.18 & 3.85 \\
\hline $80 \mathrm{WF+20} \mathrm{LC}$ & 69.76 & 67.58 & 4.15 \\
\hline $70 \mathrm{WF}+30 \mathrm{LC}$ & 69.24 & 67.00 & 4.30 \\
\hline $60 \mathrm{WF+40} \mathrm{LC}$ & 69.21 & 66.94 & 4.32 \\
\hline $50 \mathrm{WF}+50 \mathrm{LC}$ & 68.78 & 66.33 & 4.77 \\
\hline $40 \mathrm{WF}+60 \mathrm{LC}$ & 68.73 & 66.19 & 4.84 \\
\hline $30 \mathrm{WF}+70 \mathrm{LC}$ & 68.38 & 65.68 & 5.26 \\
\hline 20 WF+80 LC & 68.19 & 65.39 & 5.46 \\
\hline $10 \mathrm{WF}+90 \mathrm{LC}$ & 67.59 & 64.67 & 5.74 \\
\hline 100 LC & 67.54 & 64.39 & 6.20 \\
\hline
\end{tabular}

tion with WF. As NaClO charge increases, the bleaching yield decreases due to degradation of other carbohydrates, such as cellulose and hemicellulose. The oxidation of cellulose with hypochlorite is non-specific and degradation proceeds most rapidly near a neutral pH (Lewin and Epstein, 1962).
Mixed LC and WF handsheets, with the grammage of $30 \pm 5\left(\mathrm{~g} \cdot \mathrm{m}^{-2}\right)$, were produced and optical properties of these handsheets are presented in Table 6 .

In Table 6, it can be clearly seen that as LC ratio increased, the whiteness and brightness values decreased and the yellowness value increased. The optical properties of the LC pulps bleached by the above methods were lower than those of WF. Therefore, the brightness and whiteness values of the mixed pulp decreased.

The physical properties of the paper manufactured with mixed pulps are given in Table 7. This table indicates that increased LC ratio in the mixture significantly reduced the breaking length of the paper. This may be due to the fact that WF has longer fibers than LC as mentioned in the introduction. Several researchers found that the fiber length directly affects the physical properties of the paper. This finding led to the conclusion that long fibers are stronger than short fibers (Diaz et al. 2007; Beg and Pickering, 2008; Thumn and Dickson, 2013; Tutus and Cicekler, 2016).

In European and international trade, both water absorption time and water retention value represent important parameters for comparison of the tissue product (Anon., 2011; Tutus et al., 2016). When compared with WF, the water retention value increased

Table 7 Physical properties of tissue paper obtained with mixed pulps

Tablica 7. Fizikalna svojstva upijajućeg papira proizvedenoga od različitih smjesa pulpe

\begin{tabular}{|c|c|c|c|c|c|c|}
\hline $\begin{array}{l}\text { Mixture rates, \% } \\
\text { Omjer smjese, \% }\end{array}$ & $\begin{array}{c}\text { Thickness } \\
\text { Debljina, } \\
\mu \mathrm{m}\end{array}$ & $\begin{array}{c}\text { Density } \\
\text { Gustoća, } \\
\mathrm{g} \cdot \mathrm{cm}^{-3}\end{array}$ & $\begin{array}{c}\text { Bulkiness } \\
\text { Obujmnost } \\
\mathrm{cm}^{-3} \cdot \mathrm{g}\end{array}$ & $\begin{array}{c}\text { Breaking } \\
\text { length } \\
\text { Duljina } \\
\text { lomljenja } \\
\text { m } \\
\end{array}$ & $\begin{array}{l}\text { Water absorp- } \\
\text { tion time } \\
\text { Vrijeme upijanja } \\
\text { vode } \\
\mathrm{s}\end{array}$ & $\begin{array}{c}\text { Water retention } \\
\text { value } \\
\text { Vrijednost } \\
\text { zadržavanja vode } \\
\mathrm{g} \cdot \mathrm{m}^{-2}\end{array}$ \\
\hline $100 \mathrm{WF}$ & 103 & 0.30 & 3.34 & 1319.94 & 2.62 & 267.50 \\
\hline $90 \mathrm{WF}+10 \mathrm{LC}$ & 104 & 0.30 & 3.31 & 1159.34 & 2.21 & 271.80 \\
\hline $80 \mathrm{WF}+20 \mathrm{LC}$ & 106 & 0.28 & 3.52 & 1030.99 & 1.99 & 279.70 \\
\hline $70 \mathrm{WF}+30 \mathrm{LC}$ & 108 & 0.29 & 3.40 & 919.23 & 1.74 & 288.20 \\
\hline $60 \mathrm{WF}+40 \mathrm{LC}$ & 112 & 0.29 & 3.48 & 750.52 & 1.67 & 293.60 \\
\hline $50 \mathrm{WF}+50 \mathrm{LC}$ & 117 & 0.26 & 3.90 & 803.30 & 1.43 & 295.30 \\
\hline $40 \mathrm{WF}+60 \mathrm{LC}$ & 124 & 0.25 & 3.94 & 753.18 & 1.26 & 301.20 \\
\hline $30 \mathrm{WF}+70 \mathrm{LC}$ & 128 & 0.25 & 4.01 & 377.67 & 1.07 & 307.00 \\
\hline $20 \mathrm{WF}+80 \mathrm{LC}$ & 131 & 0.25 & 4.08 & 352.61 & 0.98 & 312.50 \\
\hline $10 \mathrm{WF}+90 \mathrm{LC}$ & 131 & 0.25 & 3.92 & 242.20 & 0.85 & 316.00 \\
\hline $100 \mathrm{LC}$ & 135 & 0.25 & 3.93 & 218.68 & 0.76 & 320.40 \\
\hline
\end{tabular}




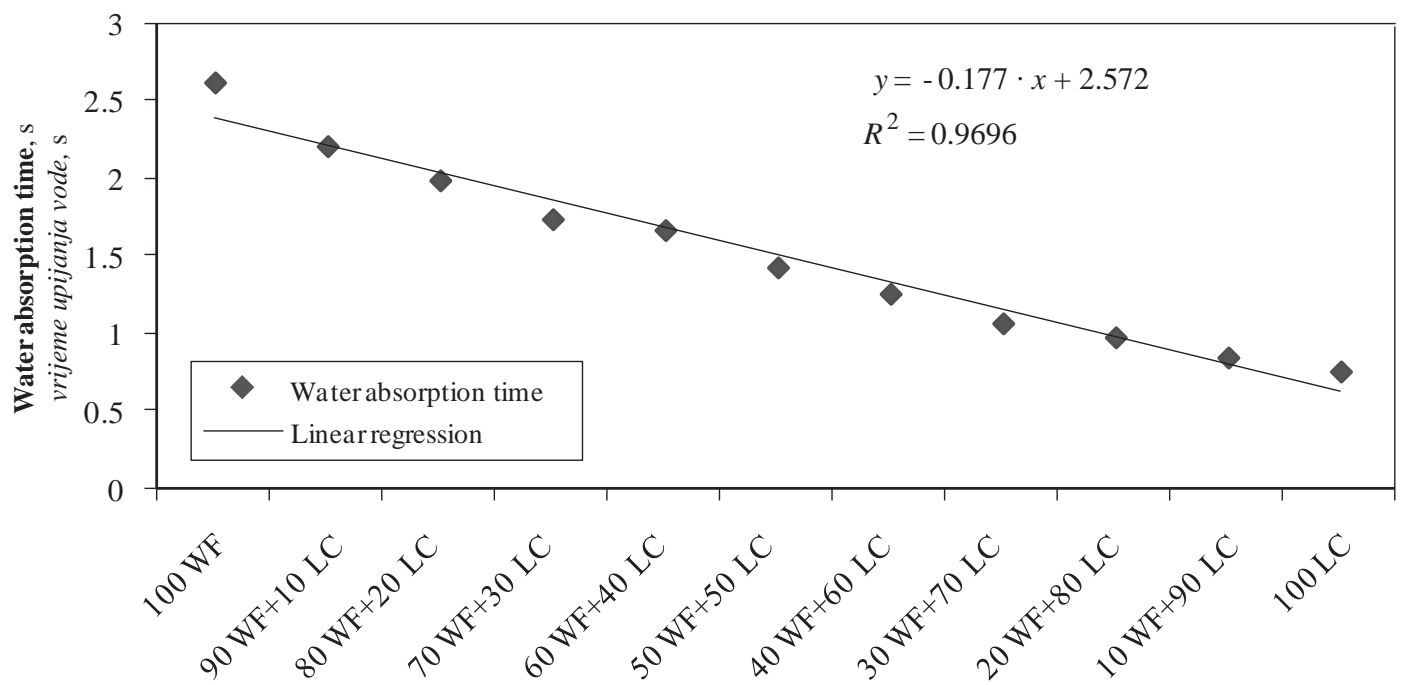

Figure 2 Water absorption times of tissue papers

Slika 2. Vrijeme upijanja vode upijajućih papira proizvedenih od različitih smjesa pulpe

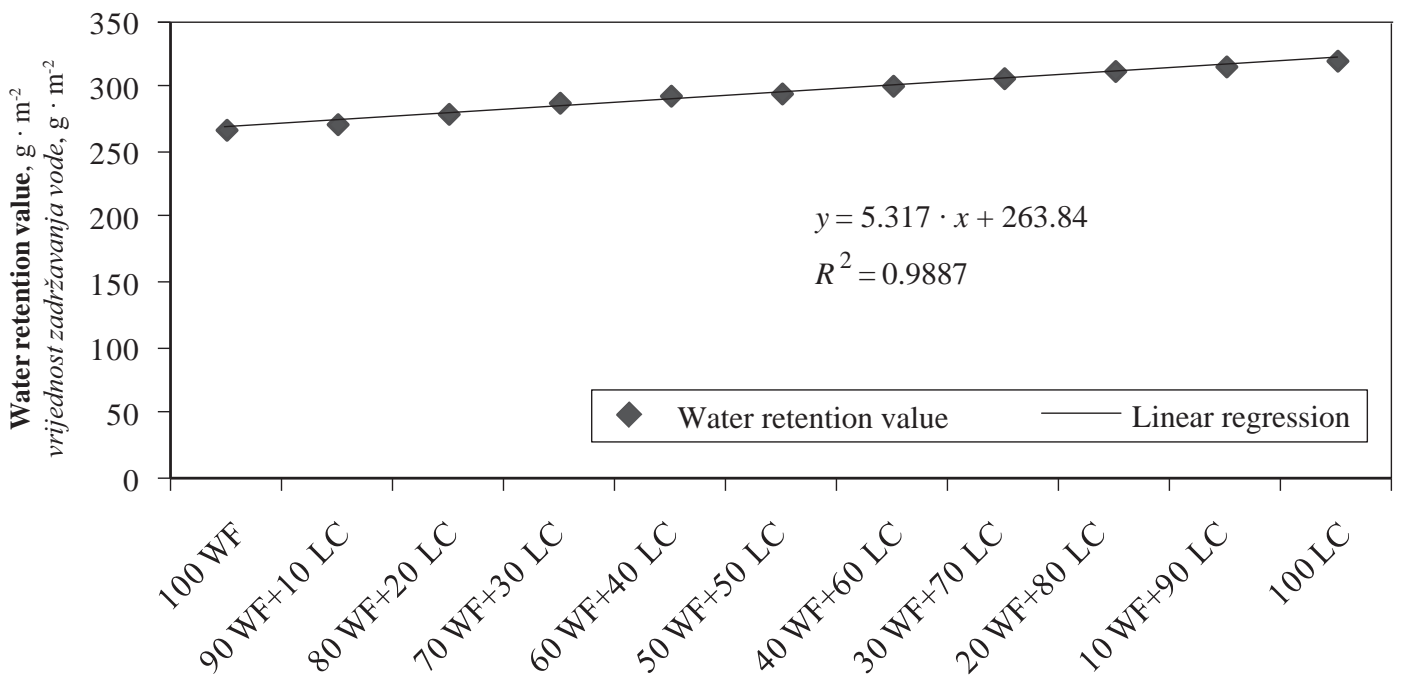

Figure 3 Water retention values of tissue papers

Slika 3. Vrijednosti zadržavanja vode upijajućih papira proizvedenih od različitih smjesa pulpe

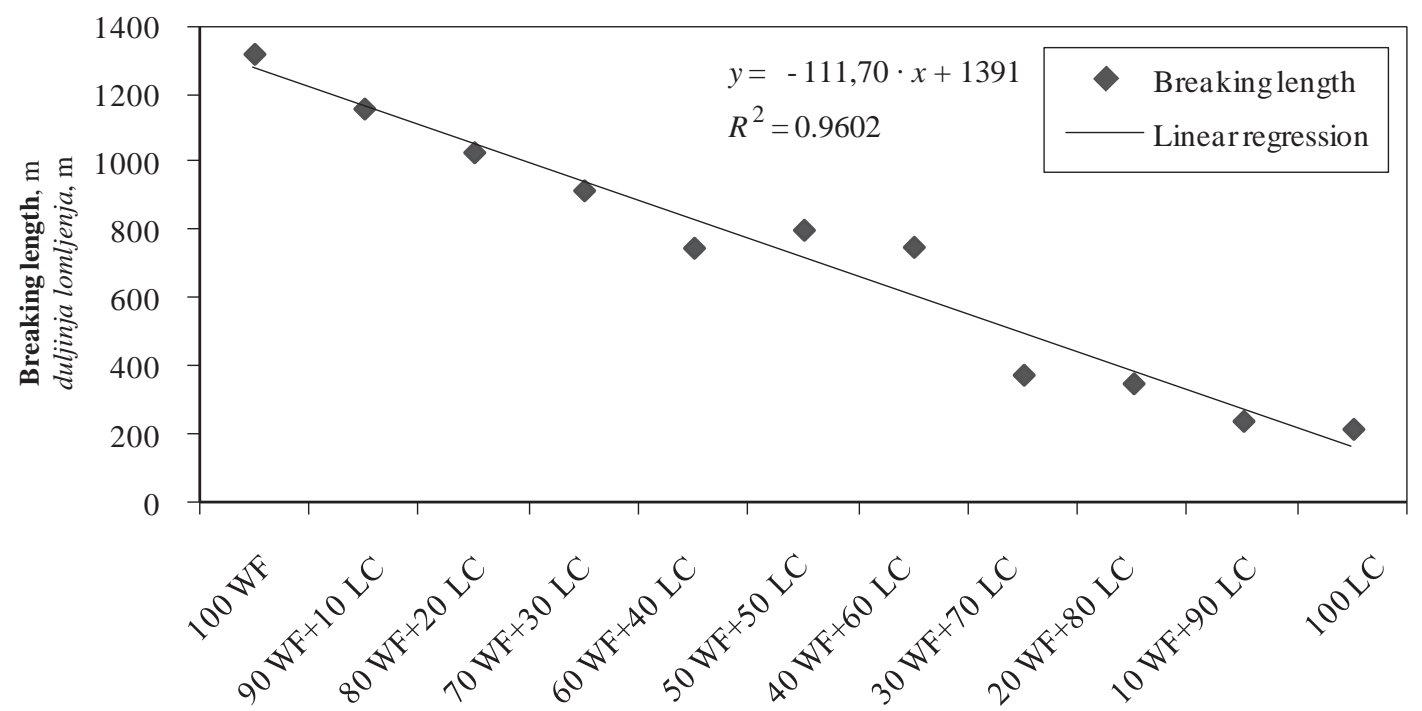

Figure 4 Breaking length values of tissue papers

Slika 4. Duljina lomljenja upijajućih papira proizvedenih od različitih smjesa pulpe 


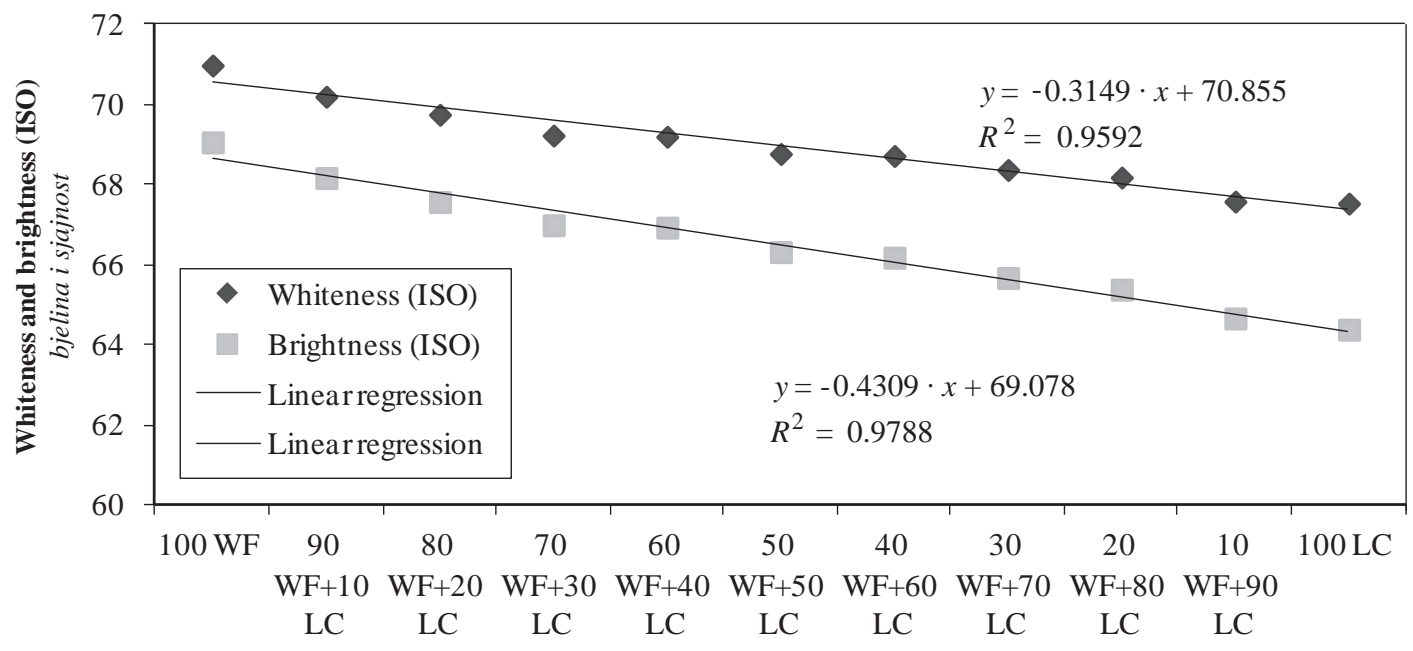

Figure 5 Whiteness and brightness values of tissue papers

Slika 5. Bjelina i sjajnost upijajućih papira proizvedenih od različitih smjesa pulpe

about $120 \%$ and the water absorption time of the tissue paper decreased about $344 \%$ with increasing LC pulp ratio (Table 7). These values have an important role in determining the quality of the tissue paper. On the contrary, the breaking length of the tissue paper reduced with increasing LC pulp ratio.

Fig. 2, 3, 4, and 5 present water absorption time, water retention value, breaking length, whiteness and brightness values of the tissue paper in order to determine the relationship between LC ratios.

Linear correlations with regression coefficients $R^{2}=0.97,0.99,0.96$, and 0.96 were found for water absorption time, water retention value, breaking length, whiteness and brightness, respectively. It can be obviously seen that there is strong correlation between LC ratios and these values.

\section{CONCLUSION}

\section{ZAKLJUČAK}

1. It was determined that the optimal bleaching conditions for LC pulps were $12 \% \mathrm{NaClO}$ at $8 \%$ consistency. Using bleached LC pulps, these conditions are suitable for tissue papermaking. These pulps can be used mixed with bleached wood pulps in tissue paper production.

2. LC pulps bleached with $\mathrm{NaClO}$ have lower optical properties than bleached WF. The optical properties can be further improved, but the bleaching was performed in mild conditions due to loss yield and degradation of other carbohydrates. On the other hand, some important properties for tissue paper, such as water absorption time and water retention value, were better than those of WF.

3. Some physical and optical properties showed a strong logarithmical correlation with LC pulps ratio. The breaking length, whiteness, brightness and water absorption time decreased with increasing LC pulp ratio, while on the contrary, the water retention values increased.
4. When examining the optical and physical properties of the tissue paper produced with LC and WF mixture, it was determined that tissue paper can be manufactured with $40 \%$ LC and $60 \%$ WF mixture.

5. Evaluation of linter could increase the availability of fibers in countries such as Turkey, where wood resources are limited. The use of linter cellulose in the paper production would be a great contribution to the economy.

6. Turkey has an important potential in the production of linter cellulose. The assessment of this potential will have positive effects on both Turkey's development and its economy.

\section{Acknowledgement - Zahvala}

This research was supported by the Kahramanmaraş Sütçü İmam University, Research Project Coordination Unit; under project number 2013/6-12 YLS.

\section{REFERENCES}

\section{LITERATURA}

1. Anonymous, 2011: ISO 12625-8, Tissue paper and tissue products, Part 8, Water-absorption time and water-absorption capacity.

2. Beg, M. D. H.; Pickering, K. L., 2008: Mechanical performance of Kraft fibre reinforced polypropylene composites: Influence of fibre length, fibre beating and hygrothermal ageing. Composites: Part A, Applied Science and Manufacturing, 39: 1748-1755.

https://doi.org/10.1016/j.compositesa.2008.08.003

3. Cardamone, J. M.; Marmer, W. N., 1995: The Whitening of Textiles. In: Carr C.M. (ed.). Chemistry of the Textile Industry. New York: Blackie Academic \& Professional, 46-66. https://doi.org/10.1007/978-94-011-0595-8_2

4. Chandra, M., 1998: Use of nonwood plant fibers for pulp and paper industry in Asia: Potential in China. Master's Thesis, Virginia Polytechnic Institute and State University, Blacksburg, Virginia.

5. Chauhan, V. S.; Kumar, N.; Kumar, M.; Chakrabarti, S. K.; Thapar, S. K., 2011: Effect of separate and mixed refining of hardwood and softwood pulps on paper properties. Journal of Korea TAPPI, 43 (4): 1-10. 
6. Comlekcioglu, N.; Tutus, A.; Cicekler, M.; Canak, A.; Zengin, G., 2016: Investigation of Isatis Tinctoria and Isatis Buschiana stalks as raw materials for pulp and paper production. Drvna industrija, 67 (3): 249-255. https://doi.org/10.5552/drind.2016.1542

7. Diaz, M. J.; Garcia, M. M.; Eugenio, M. E.; Tapias, R.; Fernandez, M.; Lopez, F., 2007: Variations in fiber length and some pulp chemical properties of Leucaena varieties. Industrial Crops and Products, 26 (2): 142-150. https://doi.org/10.1016/j.indcrop.2007.02.003

8. Dogmaz, Z., 1994: Production of linter cellulose by soda-oxygen cooking. Master's Thesis, Karadeniz Technical University, Trabzon, Turkey.

9. Erdem, N., 2010: Cotton linters: Definition, production and usage. Journal of Textiles and Engineer, 51-52.

10. Gulsoy, S. K.; Tufek, S., 2013: Effect of chip mixing ratio of Pinus pinaster and Populus tremula on kraft pulp and paper properties. Industrial and Engineering Chemistry Research, Vol. 52, 2304-2308. https://doi.org/10.1021/ie302709e

11. Ibrahim, N. A.; Sharaf, S. S.; Hashem, M. M., 2010: A novel approach for low temperature bleaching and carbamoylethylation of cotton cellulose. Carbohydrate Polymers, 82 (4): 1248-1255. https://doi.org/10.1016/j.carbpol.2010.06.059

12. Karmakar, S. R., 1999: Chemical Technology in the PreTreatment Processes of Textiles. Elsevier Science; $1^{\text {st }}$ ed., 1-4:160-174, 181-188, India.

13. Lewin, M.; Epstein, J. A., 1962: Functional groups and degradation of cellulose oxidized by hypochlorite. J. Polym. Sci. 58: 1023-1037. https://doi.org/10.1002/pol.1962.1205816663

14. Lund, K.; Sjöström, K.; Brelid, H., 2012: Alkali extraction of kraft pulp fibers: influence on fiber and fluff pulp properties. Journal of Engineered Fibers and Fabrics, 7 (2): 30-39.

15. Morais, J. P. S.; Rosa, M. F.; Filho, M. M. S.; Nascimento, L. D.; Nascimento, D. M.; Cassales, A. R., 2013: Extraction and characterization of nanocellulose structures from raw cotton linter. Carbohydrate Polymers, 91 (1): 229-235. https://doi.org/10.1016/j.carbpol.2012.08.010

16. Paulapuro, H., 2000: Paper and Board Grades. Papermaking Science and Technology. Tappi; $1^{\text {st }}$ ed.: Fapet Oy. p. 80.

17. Perez, D. D. S.; Fauchon, T., 2003: Wood quality for pulp and paper. In: Wood Quality and its Biological Basis.
Barnett, J. R., Jeronimidis, G. (eds.); Blackwell Publishing CRC Press, Ch 7.

18. Reeve, D. W., 1996: Introduction to The Principles and Practice of Pulp Bleaching. In: Pulp Bleaching Principles and Practice Ed. By Dence, C. W., Reeve, D. W., Tappi Press, Atlanta, USA.

19. Sczostak, A., 2009: Cotton linters: An alternative cellulosic raw material. Macromol Symp., 280: 45-53. https://doi.org/10.1002/masy.200950606

20. Shackford, L. D., 2003: A comparison of pulping and bleaching of kraft softwood and eucalyptus pulps. In $36^{\text {th }}$ International Pulp and Paper Congress and Exhibition. Sao Paulo, Brazil.

21. Singh, P. S., 1978: Principles of Pulp Bleaching. In: Singh PS (Ed) The Bleaching of Pulp, $3^{\text {rd }}$ ed (pp 15-28). Tappi Press, Atlanta.

22. Thumn, A.; Dickson, A. R., 2013: The influence of fibre length and damage on the mechanical performance of polypropylene/wood pulp composites. Composites Part A: Applied Science and Manufacturing, 46: 45-52. https://doi.org/10.1016/j.compositesa.2012.10.009

23. Tutus, A.; Cicekler, M., 2016: Evaluation of common wheat stubbles (Triticum aestivum L.) for pulp and paper production. Drvna industrija, 67 (3): 271-279. https://doi.org/10.5552/drind.2016.1603

24. Tutus, A.; Cicekler, M.; Cali, A., 2016: Tissue papers in Turkey and some physical and optical properties. Süleyman Demirel University Journal of Natural and Applied Sciences, 20 (1): 98-102. https://doi.org/10.19113/sdufbed.98003

25. Ward, K. J.; Voelker, M. H.; Maclaurin, D. J., 1965: Cotton Linters as paper-making fibers: Comparative studies on rag, linters and cotton lint pulps. Tappi, 48 (11): 657650 .

\section{Corresponding address:}

\section{MUSTAFA ÇİÇEKLER, Ph.D.}

Department of Forest Industry Engineering

Faculty of Forestry, Kahramanmaraş Sütçü Imam University

46100 Kahramanmaraş, TURKEY

e-mail: mcicekler87@gmail.com 